\title{
ANALISIS DAN PERANCANGAN REPRESENTATIONAL STATE TRANSFER (REST) WEB SERVICE SISTEM INFORMASI AKADEMIK STT TERPADU NURUL FIKRI MENGGUNAKAN YII FRAMEWORK
}

\author{
Mukhammad Agus Arianto ${ }^{(1)}$ (Teknik Informatika, STT Terpadu Nurul Fikri) \\ Email :massagz@gmail.com \\ Sirojul Munir $^{(2)}$ (Teknik Informatika, STT Terpadu Nurul Fikri) \\ Email : rojulman@nurulfikri.ac.id
}

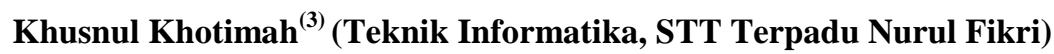

Email : kkhotimah33@gmail.com

\begin{abstract}
ABSTRAK : Kesulitan dalam mengintegrasikan data pada beberapa sistem yang berbeda menjadi salah satu masalah yang sering dialami oleh developer, mulai dari bahasa pemrograman, Platform, dan perangkat yang digunakan. Oleh sebab itu, perlu adanya pembuatan web service untuk sistem informasi akademik STT Terpadu Nurul Fikri dengan teknologi REST. Perancangan ini dibuat dua model API untuk dua modul yakni modul mahasiswa dan modul dosen. Pada modul ini akan menghasilkan data dengan format JSON. Teknik pengujian API menggunakna teknik blackbox testing dengan tools aplikasi penguji Postman. Pengujian API dilakukan pada prototype aplikasi web service. Metode penelitian yang digunakan adalah Unified Process yang menggunakan kerangka kerja Yii Framework 2.0
\end{abstract}

Kata Kunci: REST, web service,JSON, API

\section{PENDAHULUAN}

Keberadaan teknologi internet kini sudah menjadi kebutuhan yang menunjang kemudahan manusia dalam mendapatkan informasi. Hal ini ditandai dengan berkembang pesatnya teknologi informasi. Selain itu, internet juga telah mengubah cara pertukaran data dan informasi menjadi lebih cepat dan akurat. Oleh karena itu sarana komunikasi teknologi internet dimanfaatkan untuk meningkatkan produktivitas perusahaan atau organisasi.

Pengolahan data dan informasi menjadi bagian terpenting dalam suatu organisasi.semakin besar dan kompleknya suatu sistem informasi maka kebutuhan akan pengolahan dan integrasi data menjadi perhatian bagi organisasi. Proses bisnis yang berubah seiring kebutuhan organisasi sehingga diperlukan pengembangan sistem dan aplikasi yang ada.F Kapojos, Rumagit, \& Wowor, 2012). Namun, bagaimana membangun sistem dan aplikasi yang dapat digunakan kembali di masa mendatang yang dapat berjalan baik lintas platform, bahasa pemgrograman, maupun berbagai sistem operasi.

Hal tersebut yang mendasari konsep dan pemikiran lama akan sistem informasi khusunya mengenai arsitektur perangkat lunak yang terus berkembang. Service Oriented Architecutre (SOA) merupakan salah satu konsep arsitektur perangkat lunak yang menyediakan layanan bagi suatu sistem untuk bisa digunakan pada sistem lain sesuai kebutuhan. SOA bertujuan untuk memberikan layanan yang dapat diakses sistem lain, sehingga mendukung integrasi antar sistem (Thomas, 2005).

Dalam mengimplementasikan SOA, web service dapat digunakan untuk membuat pertukaran data yang diakses melalui standar internet protocol. Dalam perkembangan web service telah dikembangkan REST (Representational State Transfer) web service. Dengan mengimplementasikan REST web service dalam SOA tentu akan memudahkan pengembangan aplikasi perangkat lunak di luar sistem maupun dengan bahasa pemrograman atau platform berbeda.

Sekolah Tinggi Teknologi Terpadu Nurul Fikri merupakan perguruan tinggi teknologi yang memadukan antara keilmuan praktis di bidang teknologi informasi dengan pengembangan kepribadian islami (Menteri Pendidikan dan Kebudayaan, 2012). STT Terpadu Nurul Fikri berdiri pada tahun 2012 dan saat ini sudah memiliki lima angkatan (STT Terpadu Nurul Fikri, 2016) sehingga kebutuhan akan informasi yang mudah dan cepat sangat diperlukan guna menunjang proses kegiatan perkuliahan mahasiswa.

Di STT Terpadu Nurul Fikri kini telah terdapat sistem informasi akademik yang saat ini menggunakan pola client-server (two-tier system). Tetapi kesulitan timbul pada saat akan dikembangkan, yakni belum tersedianya layanan (web service) yang mampu 
mengintegrasikan sistem tersebut dengan sistem lain sehingga mempersulit pengembangan terutama dalam hal pertukaran, integrasi dan pengelolaan data. Oleh karenanya perlu dilakukan perancangan dan pembuatan layanan (web service) tersebut guna menyelesaikan kesulitan tersebut.

Berawal dari hal tersebut, penelitian ini merancang dan membuat REST web service sistem informasi akademik STT Terpadu Nurul Fikri yang menyediakan layanan bagi sistem lain yang membutuhkan juga menawarkan kemudahan dalam menjembatani pertukuran data tanpa mempermasalahkan perbedaan platform, ataupun bahasa pemrograman.

\section{TEORI DASAR}

\subsection{Sistem Informasi}

Sistem informasi adalah seperangkat komponen yang saling terkait yang mengumpulkan, memproses, menyimpan atau mendistribusikan informasi untuk mendukung koordinasi, pengendalian dan tahap pengambilan keputusan pada suatu organisasi. Informasi adalah data yang berhubungan dengan keputusan. (Harahap, 2013).

Menurut Abdilah,2016 Sistem informasi terdiri dari tiga konsep dasar, yaitu: masukan (input), proses (processing) dan keluaran (output). Ketiga elemen dasar ini menghasilkan informasi yang dibutuhkan untuk pengambilan keputusan, pengendalian operasi, analisis permasalahan dan menciptakan produk atau jasa baru.

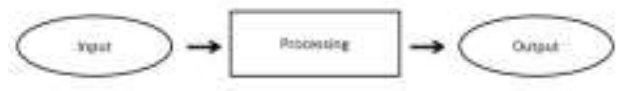

Gambar 2.1: Konsep dasar sistem informasi (Abdillah, 2006)

\subsection{Service Oriented Architecture}

Service oriented architecture atau SOA didefinisikan sebagai kebijakan, praktek, kerangka kerja yang memungkinkan fungsionalitas aplikasi disediakan dan dikonsumsi sebagai seperangkat service pada sebuah unit yang sesuai dengan kebutuhan service customer. Service dapat digunakan, dipulikasikan, ditemukan, dan diabstraksikan menggunakan standar antarmuka (Sprott \& Wilkes, 2004).

Gambar 2.2 memberikan struktur hirarki dari SOA.

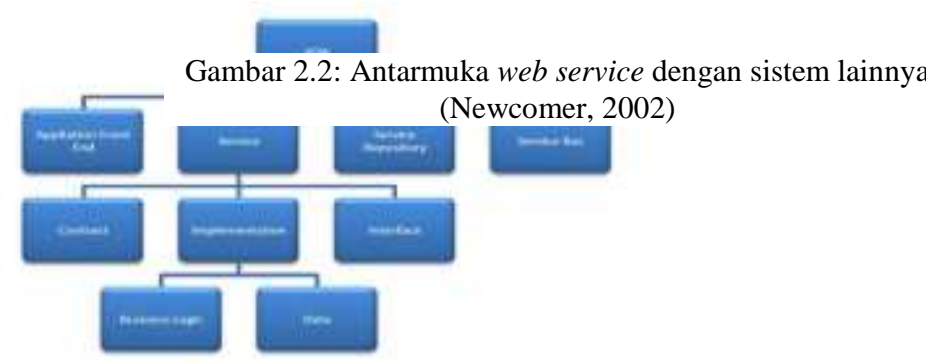

\subsection{Web service}

Web service adalah sebuah software yang dirancang untuk mendukung interoperabilitas interaksi mesin-kemesin melalui sebuah jaringan. Web service secara teknis memiliki mekanisme interaksi antar sistem sebagai penunjang interoperabilitas, baik berupa agregasi (pengumpulan) maupun sindikasi (penyatuan). Web service memiliki layanan terbuka untuk kepentingan integrasi data dan kolaborasi informasi yang bisa diakses melalui internet oleh berbagai pihak menggunakan teknologi yang dimiliki oleh masingmasing pengguna (Sutanta, 2012).

Web service bertujuan untuk meningkatkan kolaborasi antar pemrograman dan perusahaan, yang memungkinkan sebuah fungsi di dalam web service dapat dipinjam oleh aplikasi lain tanpa perlu mengetahui detil pemrograman yang terdapat di dalamnya. Ilustrasi mengenal posisi web service terhadap aplikasi lainnya dijelaskan pada gambar dibawah ini.

\subsection{REST Web service}

REST merupakan singkatan dari Representational State Transfer. Istilah REST atau RESTful pertama kali diperkenalkan oleh Roy Fielding pada disertasinya di tahun 2000 (Alonso, Casati.F, H., \& V, 2003). REST bukanlah sebuah standar protokol web service, melainkan hanya sebuah gaya arsitektur. Ide dasar dari arsitektur REST adalah bagaimana menghubungkan jalur komunikasi antar mesin atau aplikasi melalui HTTP sederhana. Sebelum adanya REST, komunikasi antar mesin atau aplikasi dilakukan dengan

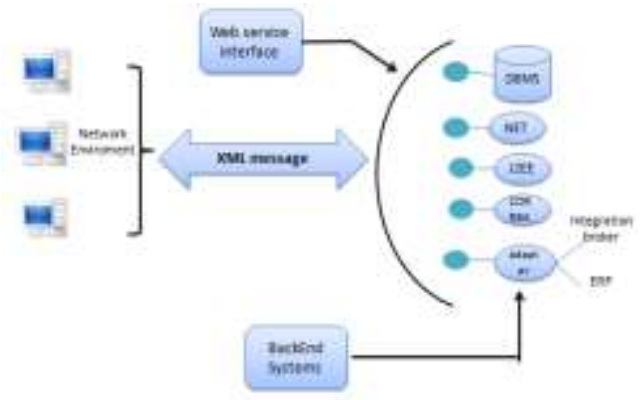

menggunakan beberapa mekanisme atau protokol middleware yang cukup kompleks seperti DCE, CORBA, RPC, ataupun SOA. 
Arsitektur REST mampu mengeksploitasi berbagai kelebihan dari HTTP yang digunakan untuk kebutuhan web service. Walaupun SOAP juga dapat menggunakan protokol HTTP, namun hanya terbatas untuk kebutuhan transport saja. HTTP sendiri merupakan sebuah protokol standar di dunia World Wide Web yang berbasis synchronous request/response. Protokol tersebut sangat sederhana: client mengirimkan sebuah request message yang mencakup HTTP method yang akan di invokasi, lokasi resource dalam format URI, serta pilihan format pesan (pada dasarnya dapat berupa format apa saja seperti HTML, plain text, XML, JSON, ataupun data binary), Kemudian server akan mengirimkan response sesuai dengan spesifikasi yang diminta oleh client. Selama ini, yang berfungsi sebagai aplikasi client adalah sebuah web browser yang memfasilitasi komunikasi antara mesin dengan manusia. Dengan adanya REST, aplikasi client dapat berupa aplikasi apa saja hanya dengan memanfaatkan HTTP.

Berikut ini beberapa prinsip arsitektur dari REST yang dikutip dari sebuah buku berjudul "RESTful Java with JAX-RS":

\section{Addressablitiy \\ 2. Constrained \& Uniform Interface \\ 3. Stateless Communication \\ 4. Format Pesan Pertukaran}

\subsection{API (Application Programming Interface).}

API merupakan software interface yang terdiri atas kumpulan instruksi yang disimpan dalam bentuk library dan menjelaskan bagaimana agar suatu software dapat berinteraksi dengan software lain. Penjelasan ini dapat dicontohkan dengan analogi apabila akan dibangun suatu rumah. Dengan menyewa kontraktor yang dapat menangani bagian yang berbeda, pemilik rumah dapat memberikan tugas yang perlu dilakukan oleh kontraktor tanpa harus mengetahui bagaimana cara kontraktor menyelesaikan pekerjaan tersebut. Dari analogi tersebut, rumah merupakan software yang akan dibuat, dan kontraktor merupakan API yang mengerjakan bagian tertentu dari software tersebut tanpa harus diketahui bagaimana prosedur dalam melakukan pekerjaan tersebut. (Reddy, 2011)

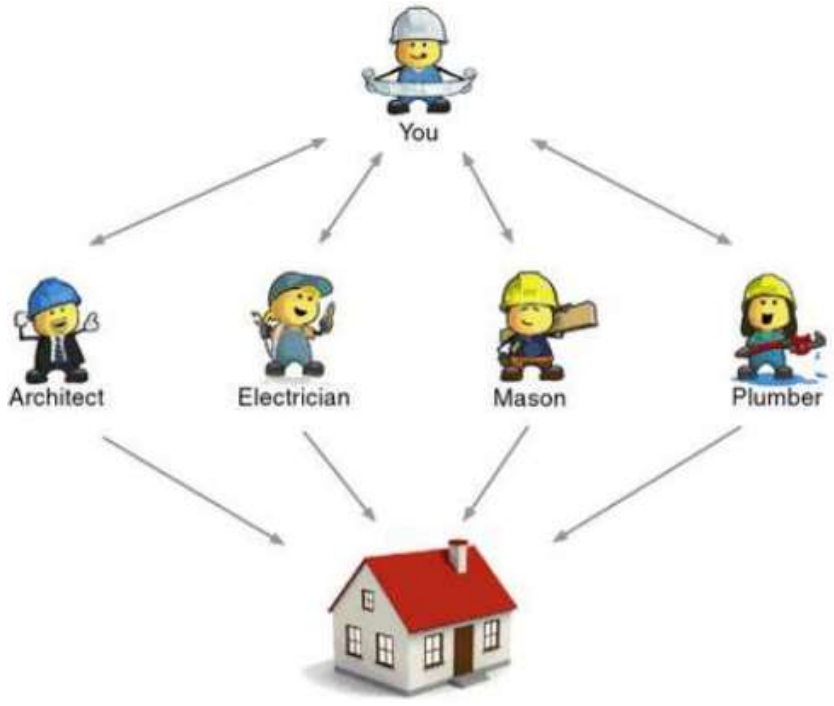

Gambar 2.3: Analogi API dalam pembangunan Rumah (Reddy, 2011)

\subsection{Model-View-Controller (MVC).}

Model-View-Controller adalah pola desain yang mengijinkan pengembang untuk membagi kode mereka menjadi tiga kategori (Myer, 2008):

a) Model untuk mengelola data

b) View untuk menampilkan data dan elemen user interface.

c) Controller menangani user events yang mempengaruhi model dan view.

Konsep hubungan Model-View-Controller selengkapnya dijelaskan pada gambar 2.7.

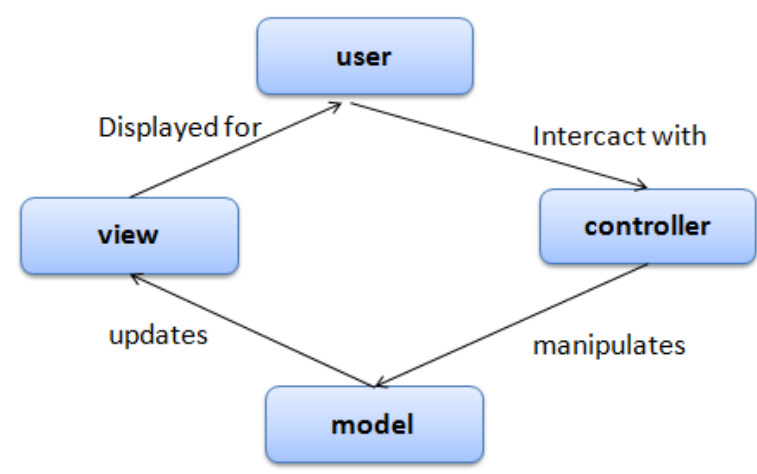

Gambar 2.4: Konsep Hubungan Model-ViewController (Myer, 2008)

MVC dipisah menjadi 3 bagian, sehingga pengembang dapat membuat multiple views dan controllers untuk banyak model tanpa mengubah desain model. 
Pemisahan ini memungkinkan untuk kemudahan pengelolaan, portable, dan mengorganisasi aplikasi. Model-View-Controller pertama kali digagas oleh peneliti Xerox PARC yang bekerja pada bahasa pemrograman smalltalk pada akhir 1970-an dan awal 1980-an. Smalltalk berorientasi objek, dynamically typed, dan bahasa pemrograman yang reflektif (Myer, 2008).

Tahap selanjutnya dari MVC yaitu dengan kedatangan sistem operasi NeXT dan perangkat lunaknya. NeXT merupakan perusahaan yang didirikan oleh Steve Jobs pada akhir 1980-an dan dibeli oleh Apple pada awal 1990-an. Pengembang MVC di NeXT menemukan cara untuk membuat view dan controller yang lebih baik (Myer, 2008).

Implementasi MVC pada dunia web yaitu dengan munculnya produk Django, Struts, dan yang sangat baik yaitu Ruby on Rails. Perangkat seperti Ruby on Rails memungkinkan tim pengembang untuk membuat aplikasi berbasis web pada waktu yang singkat, dengan sedikit proses pengujian. Situs web berbasis Ruby on Rails memiliki interface yang rapi, URL yang mudah dipahami, dan secara umum lebih lengkap dan secure daripada situs yang dibuat secara biasa dengan PHP. Keuntungan bagi pengembang web, beberapa framework PHP berbasis MVC bermunculan seperti CakePHP, Symfony, dan CodeIgniter (Myer, 2008).

\subsection{Yii 2.0 Framework}

Yii adalah sebuah framework yang digunakan untuk membuat sebuah aplikasi berbasis web yang disusun dengan menggunakan bahasa PHP. Yii merupakan sebuah web framework programming umum yang dapat digunakan untuk membangun berbagai macam aplikasi web menggunakan PHP. Sebab Yii sendiri merupakan component-based architecture dan dengan dukungan caching yang canggih dan sangat cocok untuk membangun aplikasi berskala besar seperti portal, forum, Content Management System (CMS), ecommerce, RESTful web service dan banyak lagi.

Yii memiliki dua versi utama yang tersedia yaitu: Yii 1.1 dan Yii 2.0. versi 1.1 adalah generasi lama dan sekarang ini dalam kondisi maintenance. Versi 2.0 adalah Yii yang telah disempurnakan yang mengadopsi teknologi terakhir dan protokol, termasuk composer, PSR, namespaces, traits dan lain-lain. Versi 2.0 merepresentasikan generasi framework masa kini dan akan mendapatkan fokus pengembangan lebih lanjut untuk beberapa tahun kedepan. Berikut adalah gambar yang menunjukan lifecycle dari aplikasi Framework Yii 2.0. (Yii Framework).

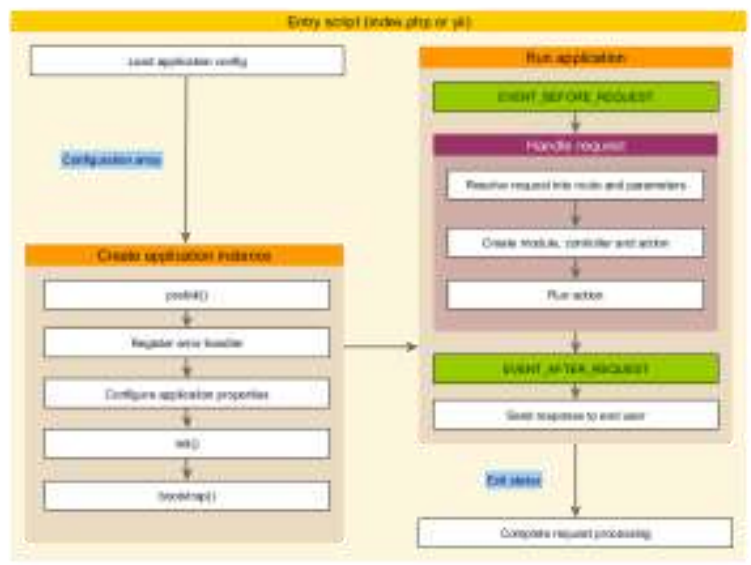

\section{KERANGKA PIKIR PENELITIAN}

tahapan-tahapan yang akan dilakukan dalam proses penyelesain penelitian dalam rangka untuk memudahkan memecahkan masalah dari awal perencanaan strategis hingga tercapainya tujuan.

Adapun tahapan-tahapan tersebut dapat dilihat pada Gambar 3.1

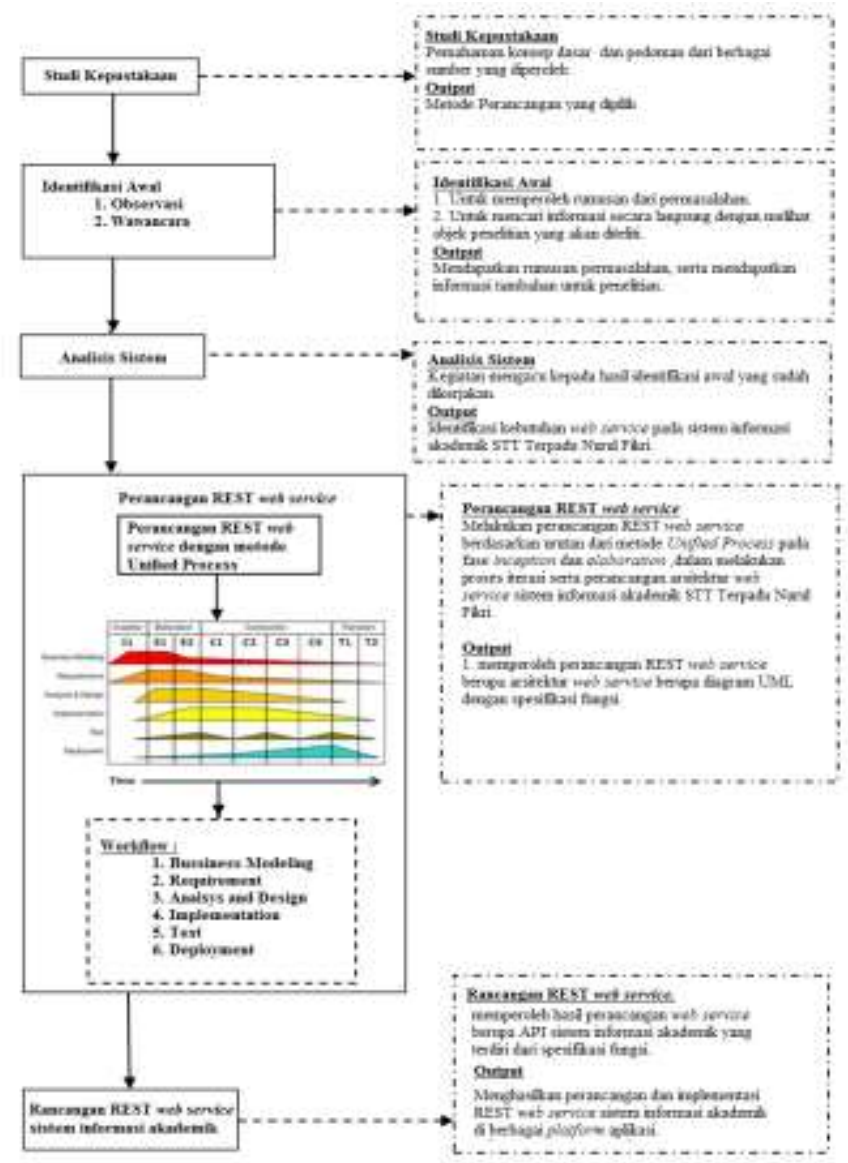

Gambar 3.5: Tahapan penelitian

\section{PEMBAHASAN DAN ANALISIS}

Analisia Kebutuhan 
Proses analisis kebutuhan pengembangan web service pada sistem informasi akademik STT Terpadu Nurul Fikri menggunnakan USDP yang dimulai dengan mendefenisikan atau menentukan persyaratan (requirements). Persyaratan tersebut terdiri atas persyaratan fungsional dan persyaratan non fungsional

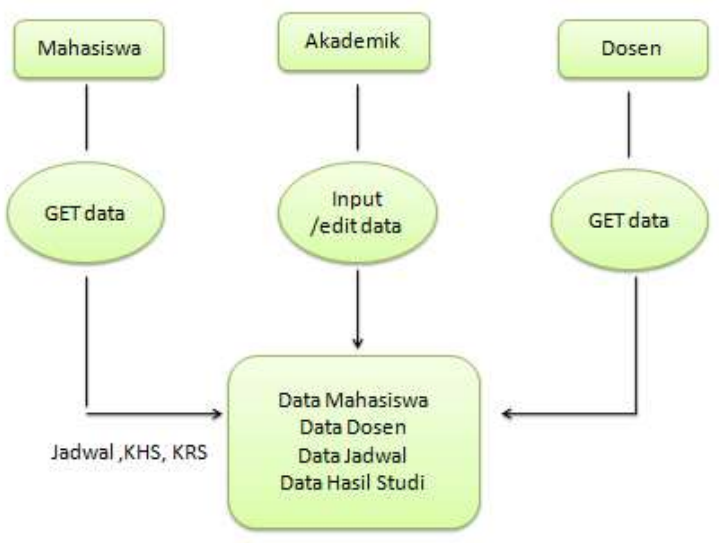

\section{Gambar 4.6 Rancangan kebutuhan web service}

\section{Analisis kebutuhan perancangan REST web service.}

berdasarkan hasil analisis kebutuhan yang dilakukan melalui observasi dan wawancara. Hasil analisis dapat dilihat pada tabel 4.1 berikut :

Tabel 4.1: Hasil Analisis kebutuhan perancangan web service

\begin{tabular}{|l|l|l|}
\hline No & $\begin{array}{l}\text { Kebutuhan } \\
\text { Perancangan }\end{array}$ & $\begin{array}{l}\text { Kondisi } \\
\text { Awal }\end{array}$ \\
\hline $\mathbf{1}$ & $\begin{array}{l}\text { Basis data SIAK } \\
\text { PostgreSQL }\end{array}$ & Tersedia \\
\hline $\mathbf{2}$ & $\begin{array}{l}\text { Framework untuk } \\
\text { membangun web } \\
\text { service }\end{array}$ & $\begin{array}{l}\text { Tidak } \\
\text { Tersedia }\end{array}$ \\
\hline $\mathbf{3}$ & $\begin{array}{l}\text { Rancangan arsitektur } \\
\text { web service }\end{array}$ & $\begin{array}{l}\text { Harus } \\
\text { dirancang }\end{array}$ \\
\hline $\mathbf{4}$ & $\begin{array}{l}\text { Format data transfer } \\
\text { Belum } \\
\text { ditentukan }\end{array}$ \\
\hline $\mathbf{5}$ & $\begin{array}{l}\text { Kandidat- kandidat } \\
\text { modul web service }\end{array}$ & $\begin{array}{l}\text { Harus } \\
\text { ditentukan }\end{array}$ \\
\hline $\mathbf{6}$ & Dokumentasi API & $\begin{array}{l}\text { Belum } \\
\text { Tersedia }\end{array}$ \\
\hline
\end{tabular}

\section{Analisis Sistem yang Berjalan}

Setelah dilakukan pengamatan pada sistem informasi akademik STT Terpadu Nurul Fikri yang dilakukan pada tahun 2015, maka sistem yang berjalan digambarkan melalui data flow diagram (DFD) berikut :

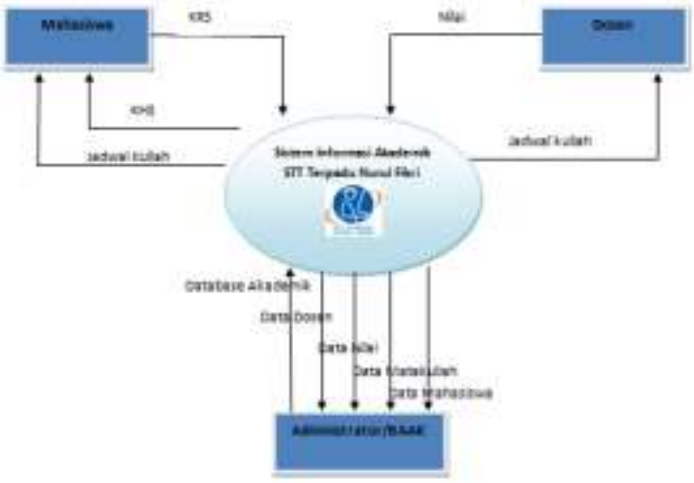

Gambar 4.7: Analisis sistem berjalan

\section{Analisis Arsitektur yang Berjalan}

sistem informasi akademik yang ada di STT Terpadu Nurul Fikri terdiri dari perangkat lunak berbasis web dimana secara fisik diletakan di beberapa web server dan terhubung dengan database server sebagai tempat penyimpanan data. Perangkat lunak tersebut hanya dapat diakses oleh web browser (komunikasi machineto-human) melalui jaringan internet. Aplikasi sistem informasi akademik tersebut hanya dapat diakses dari jaringan lokal.

Jika disederhanakan dalam sebuah model diagram, model keadaan sistem informasi yang di STT Terpadu Nurul Fikri dapat digambarkan sebagai berikut :

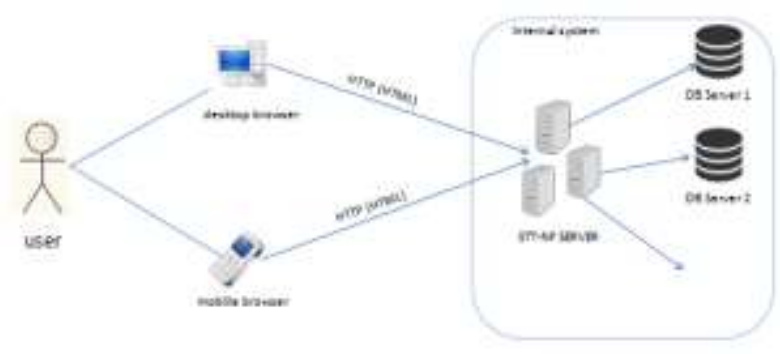

Gambar 4.8: Model Sistem kini

Berdasarkan analisis sistem dengan kondisi sistem yang telah dipaparkan sebelumnya, berikut ini diusulkan sebuah model untuk antarmuka REST web service pada sistem informasi akademik yang ada di STT Terpadu Nurul Fikri: 


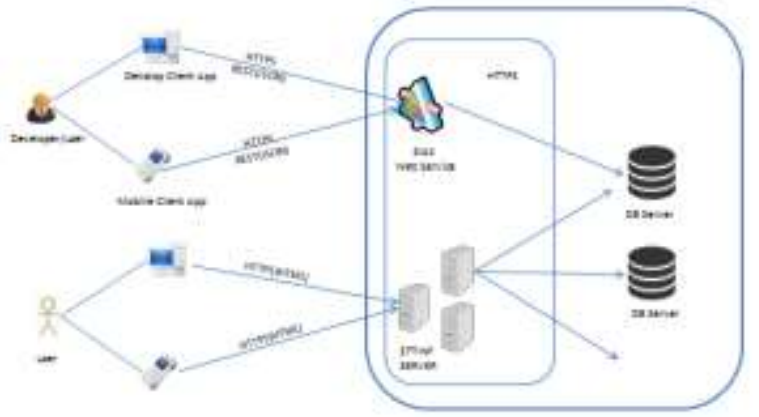

Selanjutnya sebagaimana yang tertera pada batasan masalah, manfaat dan tujuan penelitian, maka akan dikembangkan perancangan hasil implementasi dari Web service yang telah dirancang Perancangan berikut mensimulasikan mekanisme aliran data yang terjadi pada berbagai platform aplikasi.

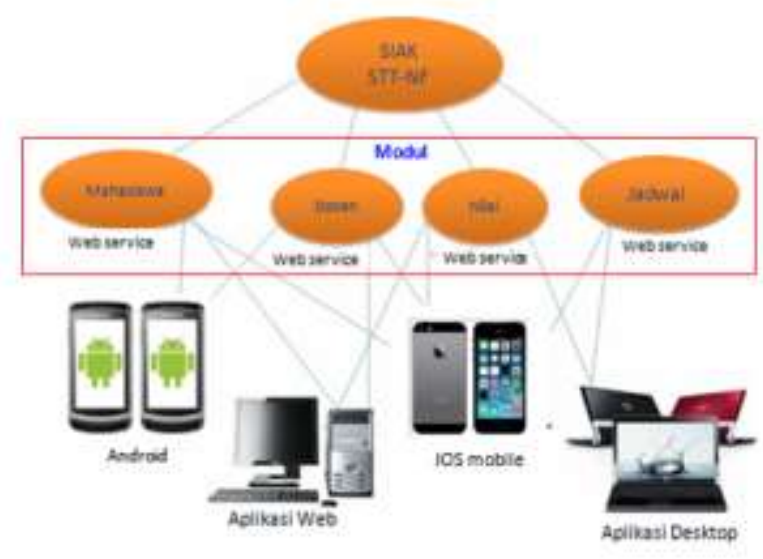

Gambar 4.9: model interoperability modul web service

Oleh karena web service yang akan dirancang menggunakan konsep Representational State Transfer (REST) dimana memungkinkan klien dapat melakukan request melalui protokol HTTP dengan mudah menggunakan URI. Struktur dari URI nya adalah sebagai berikut :

\section{https://\{nama_domain $\} /\{$ module $\} /\{$ class $\} /\{$ fungsi $\} ?\{$ parameter\}...\&\{parameter_n\}}

Dengan keterangan dapat dijelaskan sebagai berikut:

1. \{nama_domain $\}$ adalah nama domain letak API berada.

2. $\{$ module $\}$ adalah folder subdomain letak API berada.
3. $\{$ class $\}$ adalah class dimana letak API berada.

4. \{nama_fungsi $\}$ adalah nama fungsi yang akan diakses.

5. $\{$ paremeter_1\}... $\{$ parameter_n\} adalah parameter yang dikirimkan

Selanjutnya dalam perancangan skema messaging dan otentifikasi. Berikut ini menggambarkan bagaimana skema messaging dan otentikasi yang diterapkan dalam perancangan API untuk sistem informasi akademik STT Terpadu Nurul Fikri.

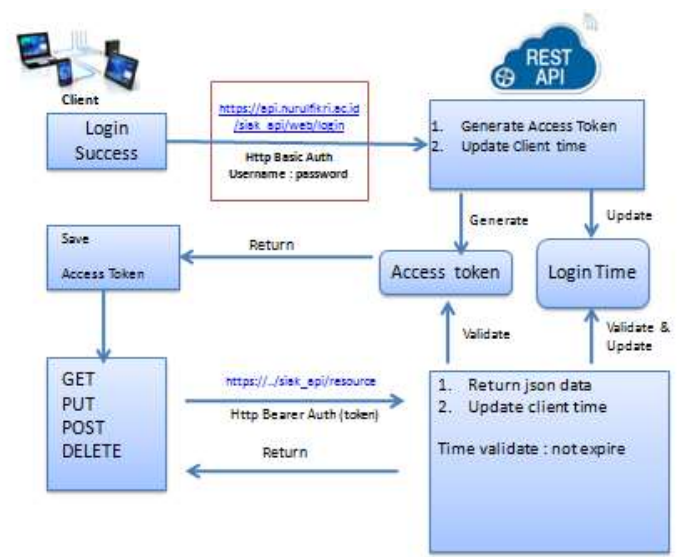

Gambar 4.10: Skema Messaging \& otentikasi token

Adapun skema messaging nya ialah melalui beberapa tahapan dalam pengaksesan URI yakni, pertama user harus login terlebih dahulu untuk mendapatkan token, kemudian server mengautentikasi request melalui Http Basic Auth. Server mengenerate token yang digunakan untuk request user. Kemudian setelah user mendapatkan token, token tersebut digunakan untuk request ke resource data. Server mengotentikasi request melalui Http Bearer Auth dimana token diletakan didalam header saat melakukan request dan memvalidasi login time. Terdapat empat macam response diantaranya sukses dengan menampilakan data JSON ,kedua token salah, token expire. Terakhir server memperbaharui login time user setelah menampilkan response data.

\section{HASIL IMPLEMENTASI}

Hasil dari Modul Mahasiswa service.

Pengujian fungsional yang dilakukan menggunakan aplikasi Postman. Data yang diuji adalah data mahasiswa yang diakses menggunakan token yang 
telah di dapatkan sebelumnya. Hasil pengujian dapat dilihat pada gambar dibawah ini :

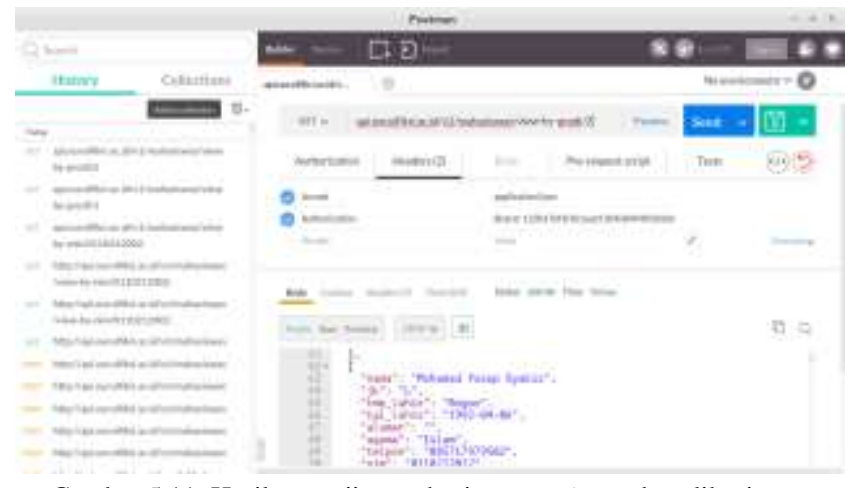

Gambar 5.11: Hasil pengujian mahasiswa service pada aplikasi Postman

Pengujian dilakukan pada aplikasi Postman pada alamat https:api.nurulfikri.ac.id/v1/mahasiswas/viewby-prodi dengan menyertakan token pada header. Untuk hasil keluaran berupa daftar mahasiswa berdasarkan prodi tertentu sesuai yang di isikan dalam parameter yang di format dalam bentuk JSON format. Hasil teks tersebut dapat dilihat secara terstruktur seperti dibawah ini :

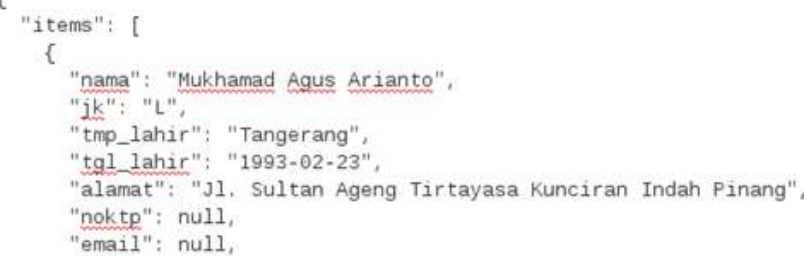

Gambar 5.12: Hasil keluaran mahasiswa service dalam format JSON

\section{Hasil dari Modul Dosen Service}

Pengujian fungsional yang dilakukan menggunakan aplikasi Postman. Data yang diuji adalah data jadwal yang diakses menggunakan token yang diselipkan di dalam header. Hasil Pengujian dapat dilihat pada Gambar dibawah ini :

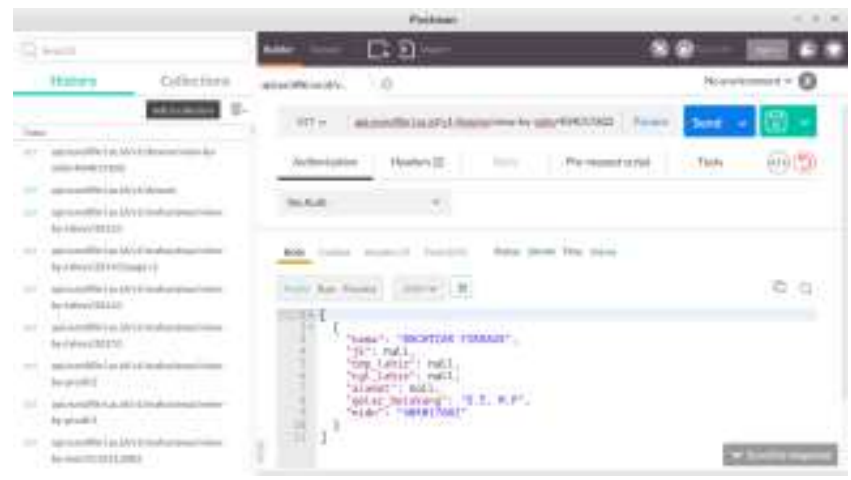

Gambar 5.13: Hasil pengujian jadwal service pada Postman

\section{Hasil pengujian dari Modul service tanpa} token

Setelah dilakukan pengujian terhadap API yang berhasil diakses dengan token, kini saatnya menguji bagaimana API yang diakses tanpa menggunakan token sebagai parameterrya. Berikut adalah gambar yang ditampilkan pada aplikasi Postman saat request API tanpa menyelipkan token pada header.

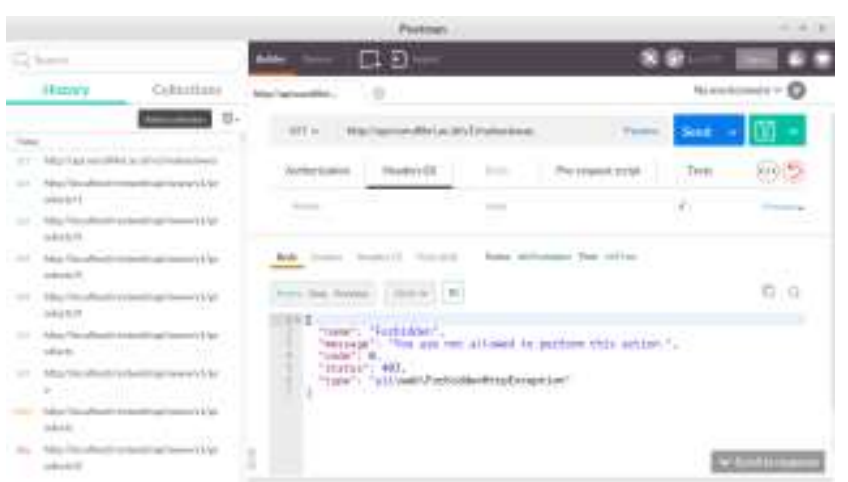

Gambar 5.14: hasil keluran modul service tanpa parameter token pada header.

\section{Pengujian API web service mahasiswa pada web client aplikasi Yii 2.0}

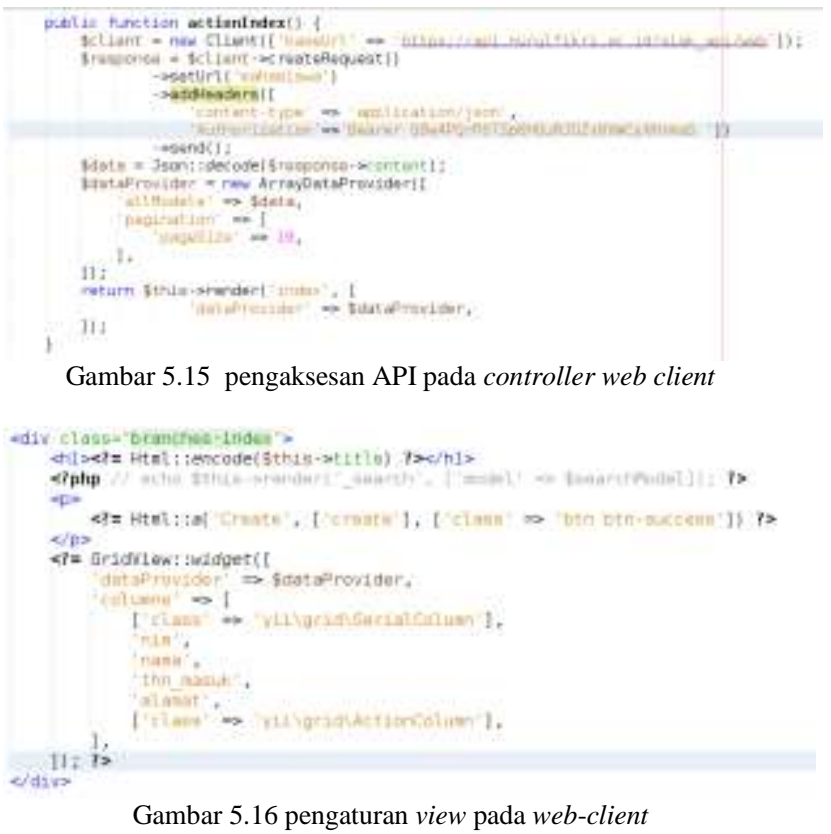




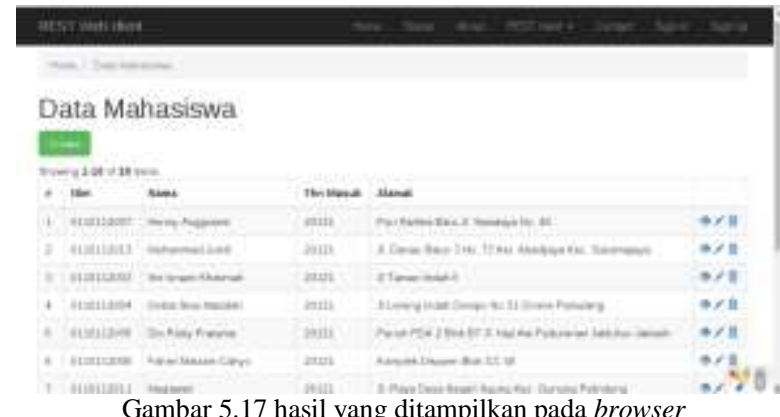

Gambar 5.17 hasil yang ditampilkan pada browser

\section{prototype web untuk dokumentasi API}

Prototype web dokumentasi berikut bertujuan untuk memberikan penjelasan mengenai API yang telah di rancang sehingga dapat dengan mudah digunakan oleh developer yang ingin menggunakan API tersebut. Berikut ini adalha tampilan awal prototype web dokumentasi API sistem informasi akademik STT Terpadu Nurul Fikri.
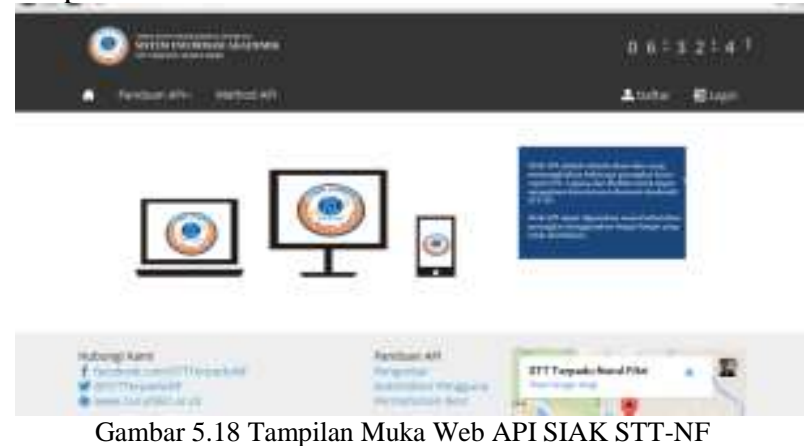

Gambar 5.18 Tampilan Muka Web API SIAK STT-NF
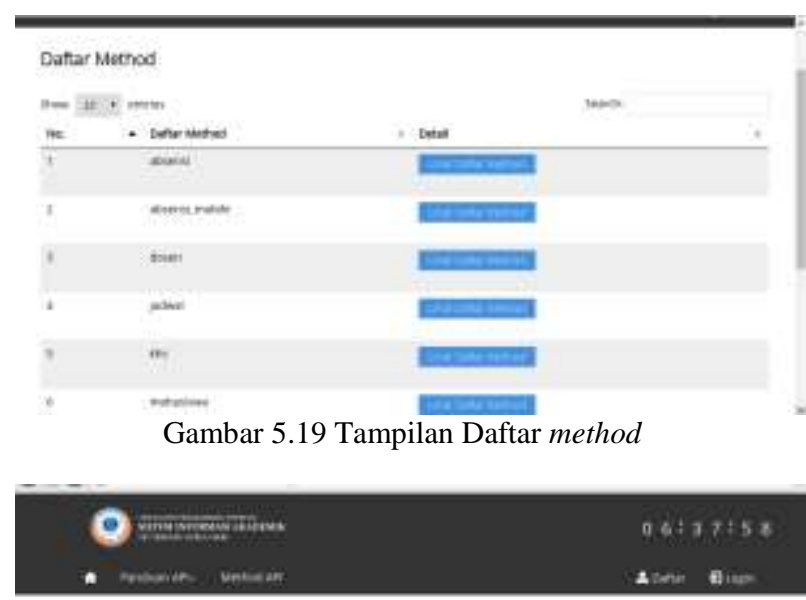

Lat Method mahasows

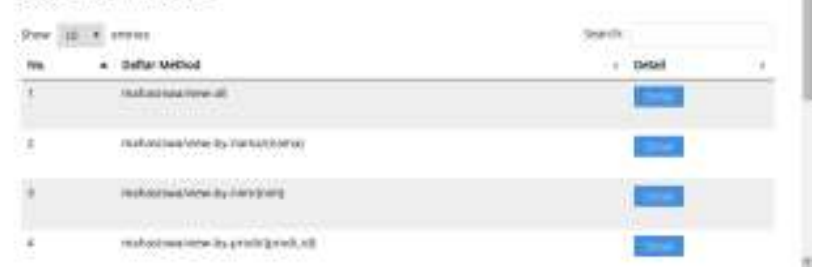

Gambar 5.20 Tampilan Method-Method kelas Mahasiswa

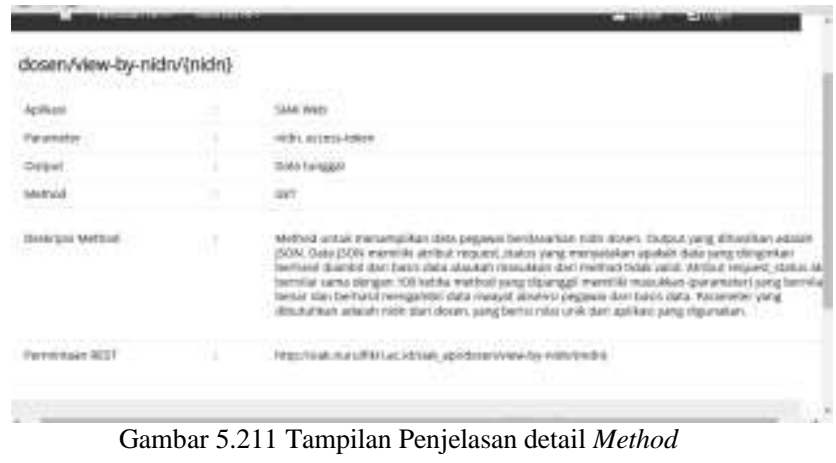

Tabel 5.2: Pengujian dengan menggunakan metode black box

\section{KESIMPULAN}

Berdasarkan hasil penelitian tugas akhir diatas dapat disimpulkan:

1. Dihasilkannya rancangan model web service sistem informasi akademik STT Terpadu Nurul Fikri berbasis teknologi REST menggunakan Yii Framework 2.0.

2. REST web service yang di rancang dan dibuat dapat di uji dengan baik dengan menggunakan tools pengujian. 